\title{
C-reactive protein and other biomarkers-the sense and non-sense of using inflammation biomarkers for the diagnosis of severe bacterial infection ${ }^{1}$
}

\author{
Tim Niehues*
}

\begin{abstract}
Severe bacterial infection (SBI) poses a significant clinical problem as its mortality and morbidity is still unacceptably high. A systematic literature analysis was performed with an emphasis on recent meta analyses examining the specificity and sensitivity of conventional inflammation biomarkers (C-reactive protein, procalcitonin, interleukin-6, interleukin-8) for diagnosing SBI. Most inflammation biomarkers do not show high sensitivity and are of limited value regarding SBI detection. To the practicing clinician, the sole use of inflammation markers is not useful for differentiating between viral or bacterial origin of infection in an individual patient. Thus, only in combination with clinical biometric markers, taken from patient history and physical examination, is the analysis of inflammation biomarkers to some degree helpful in clinical practice. To date, their sensitivity and specificity have been best captured in the field of neonatology, where levels of interleukin- 6 have been measured in combination with relevant perinatal factors. The indiscriminate use of inflammation biomarkers for the diagnosis of SBI may lead to over diagnosis. Novel technologies for pathogen detection and more precise measurement of the host-response using microarrays, allowing for simultaneous detection of multiple genes or proteins, promise to improve the value of laboratory biomarkers for the diagnosis of SBI.

Statement of novelty: Presented here is an up-to-date systematic analysis of C-reactive protein and inflammation biomarkers with regard to their use in the diagnosis of SBI. I question whether a broad use of C-reactive protein is useful in patients presenting with infection. The results of the systematic analysis are put into context with recent concerns about over-diagnosing in medicine. This paper is adapted from a publication in the German journal Monatsschrift Kinderheilkunde.
\end{abstract}

\section{Biomarker}

\section{Definition and expectations}

A biomarker (biological marker) is an objective reproducibly measureable parameter of a physiological or pathological condition that the patient cannot report her/himself (Biomarkers Definitions Working Group 2001). Biomarkers can be used to diagnose diseases or predict risks of disease complications. They can also indicate whether a drug is effective in the course of its prescription. More than 100 laboratory biomarkers exist, however, only a few have proven to be clinically useful in the context of making a diagnosis of infection. Host biomarkers can be biometric (e.g., assessment of the extent of parental concern by the physician, instinct/gut feeling of a physician) (Van den Bruel
Centre for Child Health and Adolescence, Helios Klinikum Krefeld, Krefeld, Germany
Submitted 19 January 2018

Accepted 19 March 2018

Available online 15 April 2018

${ }^{1}$ Adapted/translated by permission from Springer Nature: Springer Medizin, Monatsschrift Kinderheilkunde, C-reaktives Protein und andere immunologische Biomarker, 165:560-571, Copyright 2017. 
et al. 2012), chemical (e.g., cytokines, classical, and hematological markers) or genetic (DNA, RNA analysis). Ideally, biomarker tests can be performed at the site where the patient is treated, and is referred to as pointof-care testing (POCT) (e.g., in a general practitioner's (GP) office or in the Emergency room). To the practicing pediatrician/family doctor, a high sensitivity of the biomarker and a high negative predictive value (NPV; where there is a high probability that subjects with a negative screening test truly don't have the disease) is more important than a high specificity/positive predictive value (PPV; where there is a high probability of a negative test in a healthy non-infected patient) (Dupuy et al. 2013).

As laboratory biomarkers are often commonly used, they need to be of low cost. Otherwise, in some settings, this can drive costs for laboratory tests to an unacceptable level.

\section{Interpretation of studies on biomarkers}

In day-to-day clinical practice and in clinical research, the main aim must be to improve the condition of the sick patient (clinical endpoint) rather than his or her laboratory values/biomarkers (Strimbu and Tavel 2010). To prove that a biomarker is an effective surrogate for a clinical condition, it is necessary to have very well designed clinical studies which are of high quality. Unfortunately, these are currently lacking for most biomarkers.

The main weakness of studies and meta analyses on laboratory biomarkers is publication bias. Studies with positive results are more likely to be published than studies with results that do not show a relation between biomarker and infection. Thus, publication bias leads to a general overestimation of the value of biomarkers for making diagnoses in infectious diseases.

The use of different assays further complicates interpretation. Different inclusion and exclusion criteria for subgroups (e.g., presentation of a patient in a GP office or Emergency department, as well as differing age, sex, or concomitant diseases), inadequate randomizations, and varying definitions of endpoints/ outcome. While most investigators use the term severe bacterial infection (SBI), some may use invasive bacterial infection (IBI). Cut-off values (e.g. $>$ or $<0.5 \mathrm{ng} / \mathrm{mL}$ PCT) are arbitrarily chosen. The validity of a biomarker test relies on good standardization, reproducibility, and precision as well as pre-analytic variables such as the type of test tubes, interval between taking the probe to arrival in the lab, and usage of different culture media (Dupuy et al. 2013; Kapasi et al. 2016).

\section{Inflammation}

The major aims of inflammation are to prevent the invasion of pathogens, neutralize noxious substances, and initiate wound healing. Not every type inflammation is caused by an infection. The inflammatory or Acute Phase Response (APR) also occurs following trauma, in response to neoplasms, autoimmune disease, and exacerbation or infarctions of tissues. Clinical manifestations of the APR are fever, somnolence, and apathy. In extreme cases, uncontrolled release of cytokines (a so-called cytokine storm) may even lead to death. Once the APR has helped to contain and control the infection, subsequent fever, somnolence and inactivity are thought to be useful as they give the body time to regenerate. On a molecular basis, inflammatory cells such as macrophages and dendritic cells use sensors/ receptors (similar to scanners) to recognize a molecular pattern (likened to barcodes) on pathogens or damaged and dying cells (pathogen associated molecular patterns, PAMP, or damage associated molecular patterns, DAMP). The activation of inflammatory cells is followed by secretion of cytokines (for example interleukin (IL)-6, IL-8), hormokines (such as procalcitonin, PCT), as well as increased expression of soluble(e.g., C-reactive protein, CRP) or membrane-bound pattern recognition receptors (PRR) (Slaats et al. 2016). These markers have been subject to clinical studies to test their validity as biomarkers for inflammation. Figure 1 shows the physiological inflammatory response and the roles of molecules involved that are used as biomarkers.

\section{Significance of biomarkers regarding the differentiation between bacterial and non-bacterial infections}

Mortality and morbidity from SBI are still unacceptably high. SBI diagnosis and treatment in children is a challenge to the physician as there may be non-specific presentation, very fast disease progression, and a pathogen spectrum that varies with age (Table 1). Laboratory biomarkers could aid in the early diagnosis of SBI. Results of 2 high quality meta analyses are summarized 
I. Initiation of inflammation
II. Pattern recognition through professional antigen presenting cells
III. Cytokine mediated communication
IV. Organ activated classical inflammation signals

\section{Effector phase}

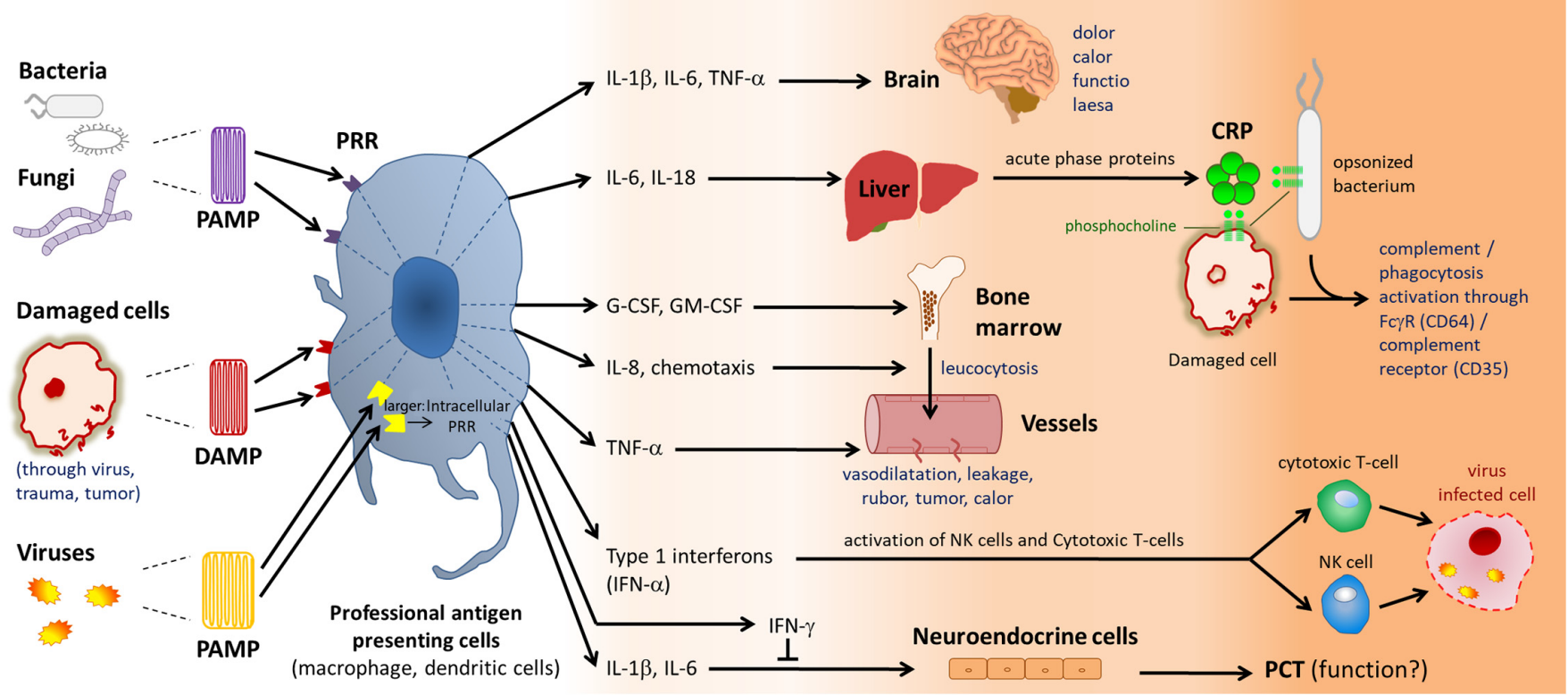

Figure 1: Physiological inflammatory response and the role of molecules involved that are used as biomarkers. The recognition of PAMP and DAMP (stimulus for inflammation) through PRR is followed by the release of pro-inflammatory cytokines IL-1 $\beta$, IL-6, IL-8, Tumor necrosis factor- $\alpha$. Activated monocytes and macrophages release granulocyte colony stimulating factor (G-CSF), granulocyte monocyte colony stimulating factor (GM-CSF). G-CSF and GM-CSF lead to an egression of leucocytes from the bone marrow and cause leukocytosis in peripheral blood. Tumor necrosis factor- $\alpha$ and IL-1 $\beta$ result in an increased expression of adhesion molecules on endothelial cells in concert with so-called chemokines (e.g., IL-8). Increased expression of adhesion molecules and chemokine expression leads to a well-concerted migration of leukocytes to the site of inflammation. Tumor necrosis factor- $\alpha$ causes vasodilatation and increased vascular permeability. This manifests as the classical clinical inflammation signs: rubor, calor, tumor. In the CNS, TNF- $\alpha, \mathrm{IL}-1 \beta$ and IL- 6 regulate the body temperature to a target value of more than $39{ }^{\circ} \mathrm{C}$ and increase pain sensation (dolor). In the liver, IL-1 $\beta$ and IL-6 lead to the release of acute phase proteins (APP) e.g., CRP, PCT, fibrinogen. In virus infections PAMP (viral nucleic acids) are predominantly recognized by intracellular PRR and their activation leads to the secretion of Type I interferons (e.g., Interferon- $\alpha$ ) and Interferon- $\gamma$ rather than IL-1, IL-6 or TNF- $\alpha$. Type I interferons activate cytotoxic T-cells and natural killer cells to lyse virus infected cells. CRP functions as a soluble PRR and opsonizes microorganisms which then can be phagocytosed. At the same time complement is activated. In contrast to CRP the precise function of PCT is unknown. Release of PCT is induced by IL-1 or CNS mediated stimulation of both neuroendocrine and normal cells in the inflammatory response. Interestingly, Interferon- $\gamma$ (which is predominantly produced in virus infections) inhibits PCT production. This figure is adapted from Niehues 2017.

in Table 2. Kapasi et al. screened 193 publications between the years of 2010 and 2015 and selected 59 of them that tested the capability of biomarkers to predict bacterial versus non-bacterial infections (Kapasi et al. 2016). Hedegaard et al. analyzed 292 publications focusing on serum or plasma biomarkers in premature babies and newborns suspected to have sepsis or septicemia, or culture-proven septicemia from $>24^{\text {th }}$ week of gestation to $28^{\text {th }}$ day of life, and determined 16 publications to be of high quality (Hedegaard et al. 2015). Largely based on these 2 meta analyses, the evidence for the usage of cytokines, classical and hematological biomarkers, and new markers is discussed.

\section{Classical inflammatory markers C-reactive protein and procalcitonin}

C-reactive protein (CRP) belongs to the group of pentraxins, a highly conserved family of pentameric proteins (Du Clos 2013). CRP binds to polysaccharides of bacterial or parasitic origin (including $\mathrm{C}$ polysaccharide of pneumococci, hence the designation) in a calciumdependent manner, and especially to phosphocholine (PC). Phosphocholines are cell membrane constituents that are detected by the immune system following damage to cells. Thus, virus infected and lysed cells, as well as cells damaged by causes other than infection, will be sensed by the immune system and recognized by CRP. 
Table 1: Infections without identifiable cause in neonates, infants, and toddlers: Age dependent pathogen profiles and frequency of severe bacterial infections. (Adapted from Niehues 2013)

SBI, severe bacterial infection; RSV, respiratory syncytial virus; GBS, group B streptococci

\begin{tabular}{|c|c|c|}
\hline Age group & Pathogens in order of frequency & $\begin{array}{c}\text { Frequency } \\
\text { of SBI }\end{array}$ \\
\hline$\leq 3 d$ & $\begin{array}{l}\text { GBS, E. coli, Staphylococcus aureus, klebsiellae, enterococci, streptococci }(A+C) \text {, } \\
\text { Listeria monocytogenes, fungi, herpes simplex virus (from maternal rectovaginal } \\
\text { flora) }\end{array}$ & $<10 \%$ \\
\hline$>3 d$ & $\begin{array}{l}\text { Coagulase-negative staphylococci,Pseudomonas, Enterobacter, Citrobacter, } \\
\text { serratiae, klebsiellae, Salmonella, Haemophilus influenza }\end{array}$ & \\
\hline Infants up to $3 \mathrm{mo}$ & $\begin{array}{l}\text { RSV, influenza A, (winter), Enterobacter (summer), GBS, Listeria monocytogenes, } \\
\text { Salmonella enteritidis, E. coli, Neisseria meningitidis, pneumococci, Haemophilus } \\
\text { influenzae b, Staphylococcus aureus }\end{array}$ & $<5 \%$ \\
\hline $\begin{array}{l}\text { Infants and toddlers } \\
\text { from } 3 \text { mo to } 6 y\end{array}$ & $\begin{array}{l}\text { Viruses, pneumococci, Haemophilus influenzae b, Neisseria meningitidis, } \\
\text { Salmonella }\end{array}$ & $<0.5 \%-1 \%$ \\
\hline
\end{tabular}

Note: Frequencies are not given with greater precision because there is great variability in reported frequencies of fever (depending on definition and method of measurement), pathogens (depending on patient group and setting-practice, emergency room, or hospital), and SBI (depending on prior treatment in peripartal period, vaccination status). The frequency may differ between countries.

Table 2: Biomarkers for the prediction of severe bacterial infections in 2 meta-analyses in newborns, children and adults (Kapasi et al. 2016), and newborns only (Hedegaard et al. 2015).

\begin{tabular}{|c|c|c|c|c|c|c|c|}
\hline Biomarker & Meta-analysis & Number of studies & $\begin{array}{l}\text { Number of } \\
\text { individuals } \\
\text { per study }(n)\end{array}$ & $\begin{array}{l}\text { Range sensitivity } \\
\text { in } \% \text { at } 0 \mathrm{~h} \text { later } \\
\text { time point }(24 \mathrm{~h})\end{array}$ & NPV & $\begin{array}{c}\text { Range } \\
\text { specificity in } \\
\% \text { at Oh later time } \\
\text { point }(24 \mathrm{~h}) \%\end{array}$ & PPV \\
\hline$\frac{\text { Hematological }}{\text { WBC }}$ & Kapasi et al. & $\begin{array}{l}28 \text { (1 blood \& CSF, } \\
22 \text { blood, } 5 \text { CSF, } \\
1 \text { synovial) }\end{array}$ & $22-1743$ & $\begin{array}{l}17-82 \\
66.7-88 \text { CSF }\end{array}$ & NR & $\begin{array}{l}53-82 \\
66-92.5 \mathrm{CSF}\end{array}$ & NR \\
\hline ESR & Hedegaard et al. & NR & NR & NR & NR & NR & NR \\
\hline \multirow{2}{*}{$\frac{\text { Classical }}{\text { CRP }}$} & Kapasi et al. & 36 & $22-1743$ & $61.2-100$ & NR & $26-100$ & NR \\
\hline & Hedegaard et al. & 10 & $20-146$ & $\begin{array}{l}\text { Oh: } 30-80 \\
\text { 24h: } 72-91\end{array}$ & $74-87$ & $\begin{array}{l}\text { Oh: } 83-100 \\
\text { 24h: } 87-100\end{array}$ & $78-100$ \\
\hline PCT & Kapasi et al. & 20 & $22-1743$ & 38-97 blood & NR & $31-100$ & NR \\
\hline$\frac{\text { Cytokines }}{\text { IL-6 }}$ & Hedegaard et al. & 8 & $68-166$ & $\begin{array}{l}\text { Oh: } 61-89 \\
24 h: 19-67\end{array}$ & $81-91$ & $\begin{array}{l}\text { Oh: } 65-96 \\
\text { 24h: } 71-97\end{array}$ & 64-95 \\
\hline \multirow[t]{2}{*}{ IL-8 } & Kapasi et al. & $\begin{array}{c}6 \text { (1 blood \& saliva, } \\
2 \text { blood, } 3 \text { CSF) }\end{array}$ & $60-83$ & 82.5-100 CSF & NR & 67.2-94 CSF & NR \\
\hline & Hedegaard et al. & 2 & $107 / 80$ & $\begin{array}{l}\text { Oh: } 62 / 75 \\
\text { 24h: 49/NR }\end{array}$ & 80/NR & $\begin{array}{l}\text { Oh: } 66 / 96 \\
\text { 24h: } 79 / N R\end{array}$ & 60/NR \\
\hline \multirow{2}{*}{$\frac{\text { Receptor }}{\frac{\text { expression }}{\text { CD64 }}}$} & Kapasi et al. & 3 & $57-1921$ & $71-96$ & NR & $87-95.2$ & NR \\
\hline & Hedegaard et al. & 3 & $32-799$ & $75-100$ & 97 & $68-100$ & 80 \\
\hline
\end{tabular}

Note: If not stated otherwise the values relate to blood samples at the time point Oh. PPV, positive predictive value; NPV, negative predictive value; CSF, cerebrospinal fluid; NR, not reported; WBC, white blood count; ESR, erythrocyte sedimentation rate; CRP, C-reactive protein; PCT, procalcitonin.

Bacteria opsonized by CRP are phagocytized by Fc receptor (CD16, CD32, CD64) -mediated phagocytosis. CRP can also activate the complement cascade.
Interestingly, in CRP knockout mice there is a significantly increased susceptibility to pneumococcal infections (Simons et al. 2014). 


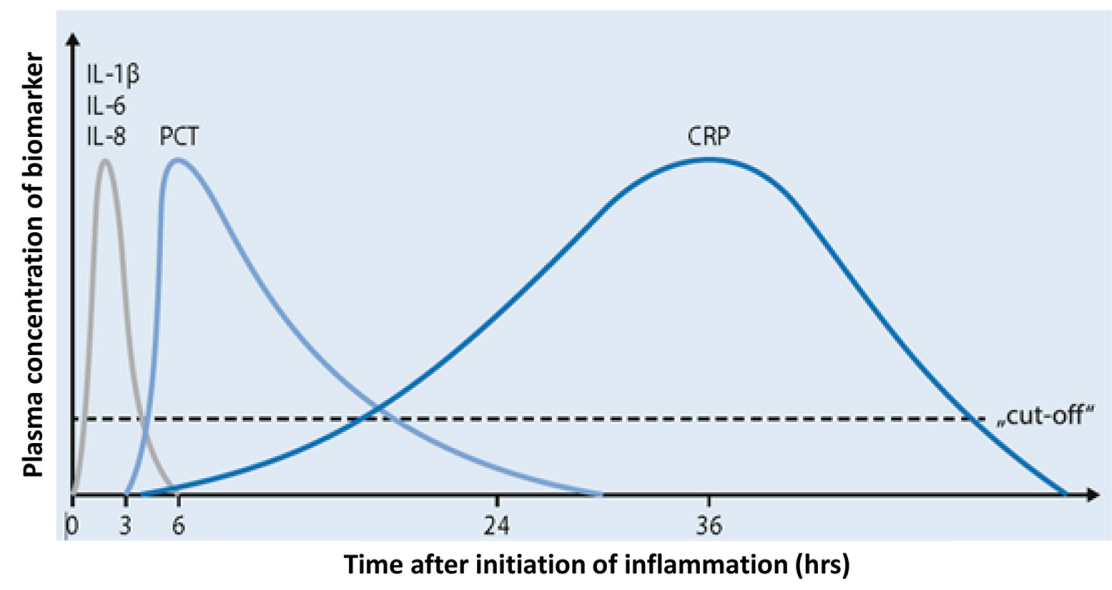

Figure 2: The kinetics of the different biomarkers. The y-axis shows an idealized cut-off and the curves are arbitrary and schematically drawn. 4-6 hours after an infection the CRP concentration rises and peak of the CRP concentration after infection is at 36 hours. In contrast, PCT already rises after 3 hours and reaches its peak after 24 hours. IL-6 and IL- 8 have an even shorter half-life and their concentrations are already beneath the cut-off level after 6 hours.

Procalcitonin (PCT) is the pro-hormone of vitamin $\mathrm{D}$-regulating calcitonin and is normally produced by neuroendocrine cells in the thyroid gland, lungs, and kidneys. In the setting of infection/septicemia, all cells of the body produce PCT (Linscheid et al. 2003; Jin and Khan 2010). CRP and PCT synthesis is incited by cell damage or bacterial constituents such as PC, lipopolysaccharides (LPS) and cytokines (especially IL-6). The advantage of using PCT for detection of SBI is the faster rise of PCT after a stimulus (e.g., infection) as compared to CRP (Figure. 2). CRP concentrations are measured in milligrams per deciliter $(\mathrm{mg} / \mathrm{dL})$ or milligrams per liter $(\mathrm{mg} / \mathrm{L})$, whereas PCT is measured in nanograms per milliliter. Concentrations of CRP $\geq 1 \mathrm{mg} / \mathrm{dL}(10 \mathrm{mg} / \mathrm{L})$ or PCT $>0.5 \mathrm{ng} / \mathrm{mL}$ are considered to be clinically significant (Kushner 2015). However, it should be emphasized that there are polymorphisms in IL- 6 and CRP genes that result in significant inter-individual differences in baseline CRP and PCT concentrations (Du Clos 2013).

Until recently, it was thought that the placenta and fetus were sterile. It has now been shown that a fetal microbiome exists and that normal placentas contain bacteria such as Lactobacillus, Bacteroides, and Bifidobacterium bifidum. These relate to the spectrum of the oral microbiome of the mother (Nuriel-Ohayon et al. 2016). Thus, in utero, there is already contact between fetal immune cells and pathogens as well as other antigens. This may explain the high concentrations of pro-inflammatory cytokines and inflammatory markers such as CRP and PCT immediately after birth.
Physiologically and in the absence of infection, CRP and PCT are significantly elevated during the first days of life (Chiesa et al. 2011). This makes their use as biomarkers in neonatology difficult, and explains why PPV or NPV values are low when used as biomarkers in the context of newborn septicemia (Table 2). The measurement of IL-6, IL-8, CRP, and PCT levels to detect infections is only useful if there is sufficient data on the history of the patient (pre-analytic values), such as premature rupture of membranes, maternal fever etc. (Table 3). Moreover, female gender, AfroAmerican descent, obesity, periodontal disease, alcoholism, diabetes mellitus, uremia, chronic fatigue, and even socioeconomic status (Liu et al. 2017) all are associated with elevated CRP levels. Mitigated CRP values can be found in systemic lupus erythematosus (SLE) as type-1 interferons, which are largely increased in SLE, inhibit CRP synthesis (Kushner 2015) (Figure. 1).

In adults, CRP values above $10 \mathrm{mg} / \mathrm{dL}$ indicate infections in $80 \%$ of cases while values above $50 \mathrm{mg} / \mathrm{dL}$ indicate infections at the rate of $88 \%-94 \%$ (Kushner 2015). Whereas elevated CRP and PCT levels may increase the likelihood that there is a bacterial infection, their capacity to differentiate between bacterial and nonbacterial infection in a single patient is very limited and not useful to the practicing clinician. Accordingly, the German "Choosing wisely" initiative on infections by the German Society of Infectious Diseases (DGI) states: Do not treat patients with an elevated CRP or PCT with antibiotics without signs of infection 
Table 3: Risk factors for severe bacterial infection.

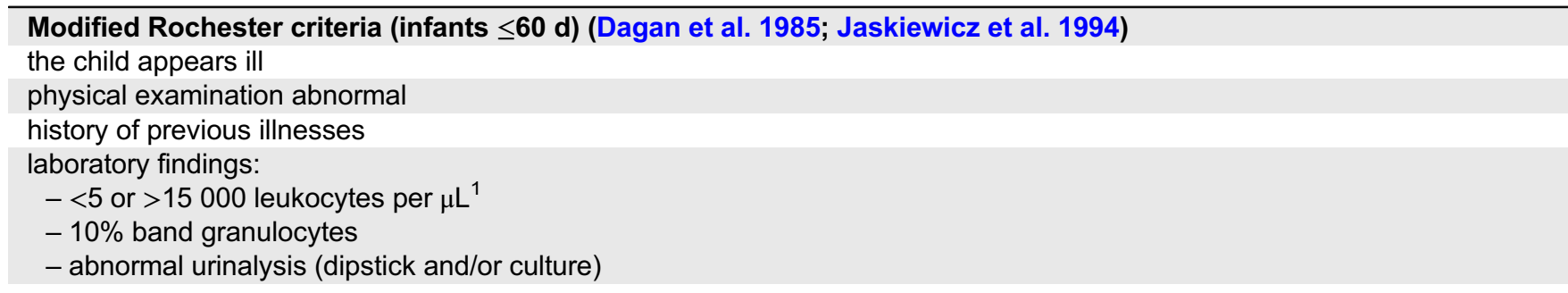

Relevant perinatal factors

mother: pathological cardiotocography (CTG), premature rupture of membranes $>18 \mathrm{hr}$ (neonates); $>12 \mathrm{hr}$ (preterm infants), maternal fever $>38{ }^{\circ} \mathrm{C}$ sub partu, uterine tenderness, foul-smelling amniotic fluid, fetal tachycardia

neonate: neonatal asphyxia, immature neutrophilic granulocytes $>20 \%$, CRP $>2 \mathrm{mg} / \mathrm{dL}^{2}$, elevated IL-6/IL-8 values

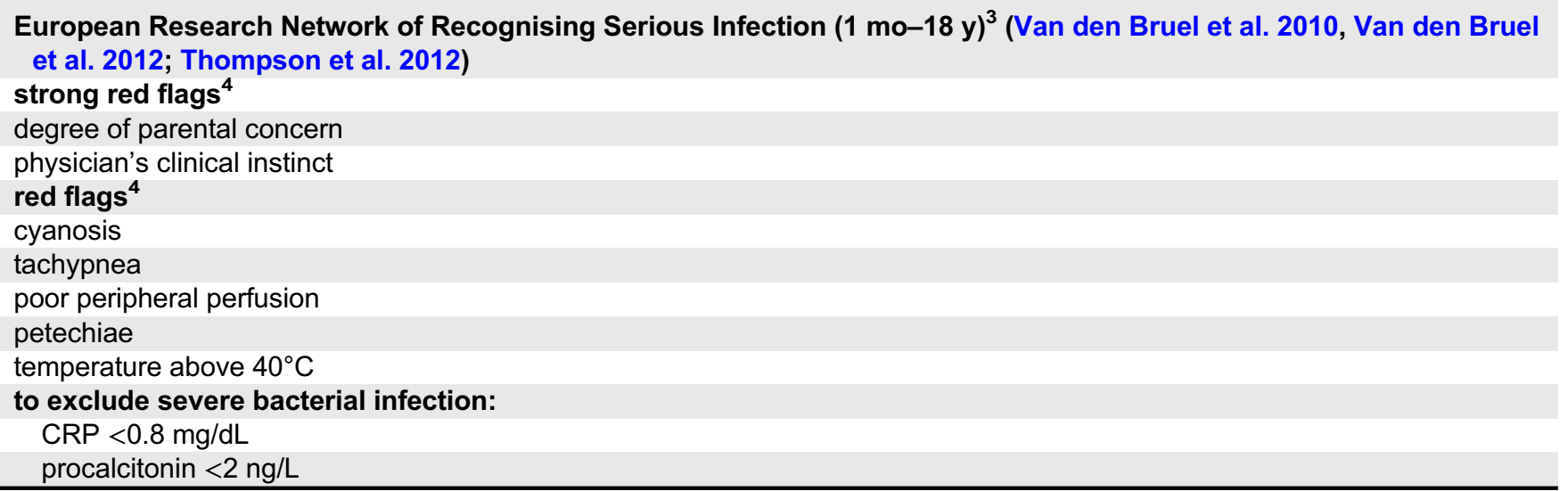

Note: Risk estimation predominantly following clinical biometric biomarkers in combination with laboratory biomarkers (adapted from Niehues 2013).

${ }^{1}$ Beware: erythroblasts.

${ }^{2}$ Physiologically elevated in neonates $24-36 \mathrm{~h}$ after birth.

${ }^{3}$ Meta-analysis of approximately 4000 studies, selection of appropriately designed studies in the outpatient setting with subjects aged 1 mo to 18 y.

${ }^{4}$ None of these parameters is sufficiently informative by itself to reliably confirm or exclude a severe bacterial infection.

(Lehmann et al. 2017). As described above, both children and adults have varying and inter-individually different levels of baseline concentrations. Very high levels of CRP and PCT are frequently found in viral infections (Toikka et al. 2000; Kruger et al. 2009). Appenzeller et al. showed a median CRP level of $49 \mathrm{mg} / \mathrm{L}$ (range $21-96 \mathrm{mg} / \mathrm{L}$ ) in 87 children at the age of 1.5 years with a proven adenovirus infection (Appenzeller et al. 2002). Toikka et al. investigated PCT, CRP, and IL-6 serum concentrations in children with pneumonias of proven bacterial or viral origin in 126 children at the age of 3 years (Toikka et al. 2000) (Figure. 3). On admission to the hospital, children with bacterial pneumonias had significantly higher PCT and CRP values as compared to children with viral pneumonias. However, as demonstrated in Figure 3 values overlap significantly.

\section{Is procalcitonin superior to CRP for SBI detection?}

In some analyses PCT shows somewhat better results than CRP. In children up to the age of 36 months, PCT was better for the early recognition of SBI than CRP regarding sensitivity and specificity (Yo et al. 2012). In a French multi-center study assessing 2047 infants $\leq 3$ months of age (body temperature $>38^{\circ} \mathrm{C}$ ), a PCT screening (cutoff-level $>0.3 \mathrm{ng} / \mathrm{mL}$ PCT) was better than CRP regarding IBI but not SBI (Milcent et al. 2016). Again, sensitivity was $90 \%$ for IBI and $<78 \%$ for SBI. The use of clinical algorithms in connection with laboratory biomarkers are much more successful at detecting SBI than the use of single biomarkers such as PCT or CRP alone.

\section{Cytokine biomarkers}

IL-6 is the most commonly used cytokine biomarker. It is produced very early after infection by hepatocytes, endothelial cells, chorion and amnion cells as well as trophoblasts. IL-6 has a very short half-life of about 100 minutes (Waage et al. 1989; Machado et al. 2014). IL-8 (CXCL8) is a pro-inflammatory chemokine 

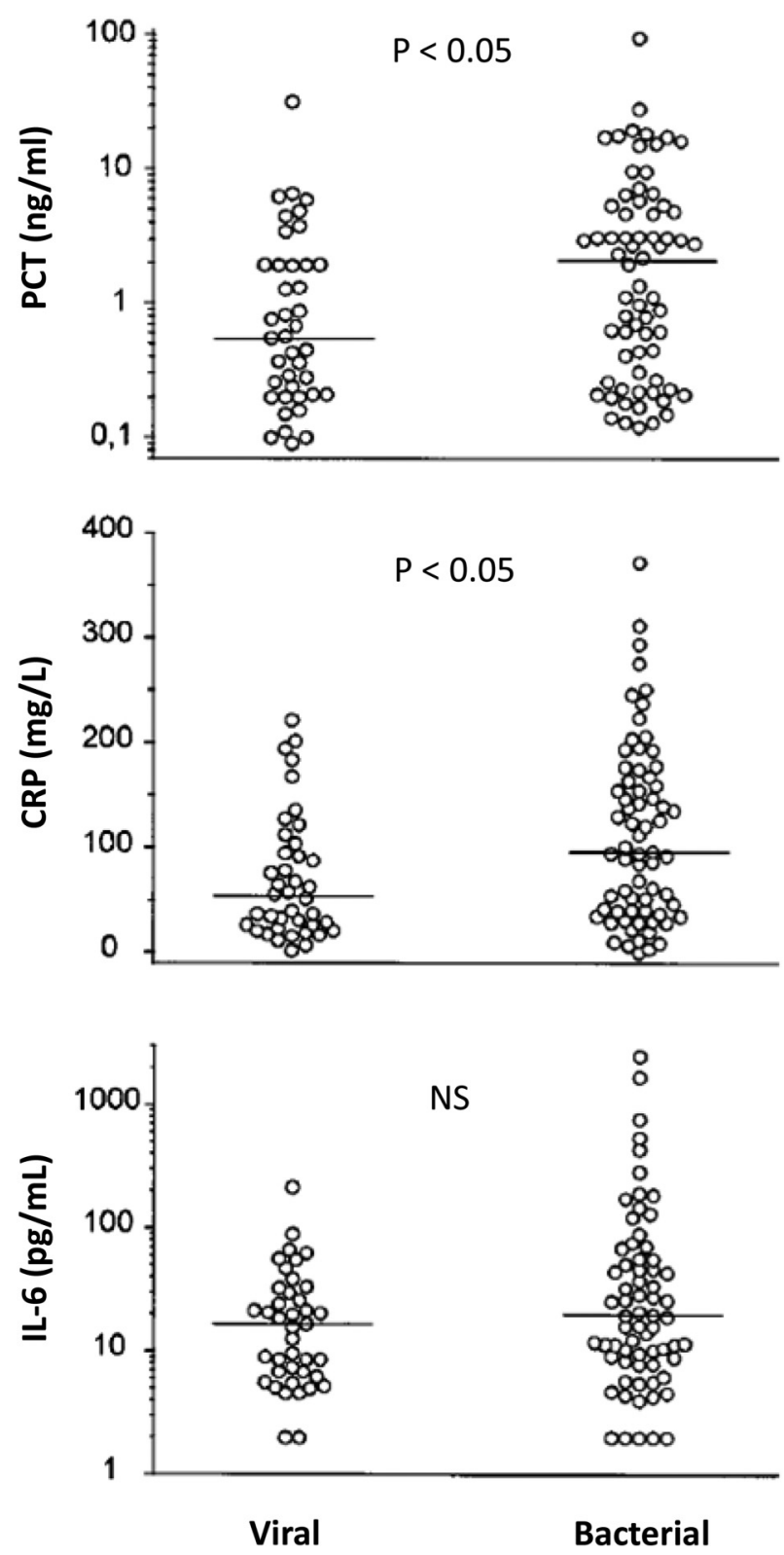

Figure 3: PCT, CRP, and IL-6 serum concentrations in children with pneumonias of proven bacterial versus viral origin in 126 children at the age of 3 years. Children were tested for PCT, CRP and IL-6. On admission to the hospital children with bacterial pneumonias had a significantly higher PCT (median $2.09 \mathrm{ng} / \mathrm{mL}$ versus $0.56 \mathrm{ng} / \mathrm{mL}, P=0.019$ ) and higher CRP values (96 mg/L versus $54 \mathrm{mg} / \mathrm{L}, P=0.008$ ) as compared to children with viral pneumonias (Toikka et al. 2000). However, values overlap significantly. IL-6 concentrations did not differ significantly between the 2 patient groups. PCT values $>2 \mathrm{ng} / \mathrm{mL}$, CRP values $>150 \mathrm{mg} / \mathrm{L}$ or IL6 $>40 \mathrm{pg} / \mathrm{mL}$ had a specificity of more than $80 \%$ for bacterial pneumonia. This means that in approximately $20 \%$ of cases these biomarkers were not predicting correctly. The sensitivity is only $50 \%$ for PCT, $31 \%$ for CRP, and $34 \%$ for IL- 6 . produced 1-3 hours after an inflammatory stimulus (by monocytes, macrophages, and endothelial cells including placenta cells) and has a very short half-life of about 4 hours. IL- 8 regulates leukocyte migration and activation. The concentrations of IL- 6 and IL- 8 are given in picogram $/ \mathrm{mL}$. Due to their very short half-lives, IL-6 and IL- 8 have been found useful in the prediction of newborn septicemia. Meta-analyses show relatively high values regarding sensitivity/NPV (IL-6: 61-89/81-91; IL-8: 62-75/80; CRP: 30-80/74-87) (see Table 2).

\section{Hematological biomarkers}

The erythrocyte sedimentation rate (ESR) refers to the rate in which erythrocytes sink in a test tube after blood has been drawn. The speed at which erythrocytes sink is given in $\mathrm{mm} / \mathrm{h}$ and is dependent on the extent to which erythrocytes are loaded with acutephase proteins such as fibrinogen and immunoglobulins, and also relates to plasma viscosity. The ESR value is very well suited to identifying infections from many other diseases. ESR may be artificially elevated in advanced age, female gender, anemia, renal insufficiency, and obesity. ESR is mitigated in leukocytosis or in hypofibrinogenemia.

A blood count, differential blood count, and in particular number of leukocytes have good predictive values only if used in connection with clinical biometric markers (Hornik et al. 2012). Values for sensitivity of ESR range from $77.4 \%$ to $85 \%$, and for leukocyte number from $17 \%$ to $82 \%$. Thus, hematological biomarkers appear less suitable for the differentiation between bacterial and non-bacterial infection as compared to other markers (Table 2).

\section{Clinical biometric markers}

There is no single laboratory biomarker that can reliably predict infections without proper information regarding patient history and clinical signs (preanalytic values). Clinical biometric biomarkers are much more important for the early recognition of SBI than laboratory markers (van den Bruel et al. 2010) (Table 3). The usage of the modified Rochester criteria to exclude SBI corresponds to a very high NPV value of $98.9 \%$ (Jaskiewicz et al. 1994). In the less severe forms of pediatric community acquired pneumonias (Bradley et al. 2011; Friedman et al. 2014) the management of pneumonias and bronchiolitis can be successfully done without routine blood tests. 


\section{Management of infections in different settings}

\section{Is a general screening with laboratory biomarkers useful in the GP office or in the Emergency room?}

A general CRP screen of all children that present to an Emergency room is not useful. A recent study in Belgium assessing a CRP point-of-care test (POCT) in 2773 children with a mean age of 3 years showed that CRP POCT screening in all children is not superior to selective blood sampling based on standardized clinical risk assessment (blood test taken only, if there are respiratory systems, fever above $40^{\circ} \mathrm{C}$, diarrhea in those below 30 months of age) (Verbakel et al. 2016). In another study, it was shown that a general screening with laboratory biomarkers does not reduce the prescription of antibiotics (Van den Bruel et al. 2016).

\section{Significance for using laboratory biomarkers in monitoring disease courses and steering antibiotic therapy}

It is still common practice to direct antibiotic therapy according to the course of CRP and other inflammatory markers, rather than by clinical assessment. To my knowledge, larger studies investigating the capability of inflammatory markers within a disease course were done only in newborns (examining the effect of CRP on directing antibiotic therapy), and published more than 17 and 20 years ago, respectively (Ehl et al. 1997; Bomela et al. 2000). It is still unknown how often and when in a disease course the investigation of biomarkers may be useful. Is a laboratory marker based change of treatment duration and decision-making (e.g., discharge from the hospital) in any way beneficial? In this regard, antibiotic stewardship (now established in many hospitals) may lead to a change of paradigm.

\section{Use of cytokines and classical inflammatory biomarkers in special conditions such as fever and cytopenia}

Classical markers like PCT and CRP as well as their soluble receptors (IL-6, IL-8, IL-2 receptor and tumor necrosis factor receptor) cannot differentiate between bacterial and viral infections in children and adults with fever and cytopenia. Moreover, they are not helpful for monitoring the course of patients with fever and cytopenia and are thus regarded as non-relevant (Lin et al. 2012; Phillips et al. 2012; Haeusler et al. 2013; Karakurt et al. 2014). The care of children with oncology diseases may change in the future with the advent of novel technologies to detect and monitor infections.

\section{Novel technologies}

Growing pathogens by culture is important for identifying antibiotic sensitivity of a given bacterial strain and appropriate therapy. However, due to the time it takes to obtain these results, it may not be useful for making decisions in the front-line setting of potential sepsis. False-positive or false-negative cultures are common. Diagnostic tests are now available for pathogen detection that are independent of culture media (multiplex Polymerase Chain reaction) (Zhang et al. 2015; Ziegler et al. 2016), however, these have yet to be routinely used in day-to-day clinical practice. Alternatively, rather than pathogen detection, the measurement of the host response by microarray of blood leukocytes allows for the simultaneous modular detection of more than 100 genes (so-called multigene classifiers; transcriptome) or proteins (proteome) of the immune response. In newborns and infants less than 60 days of age, these tests reached a sensitivity of $89 \%$. In older children (median 18 months of age), the sensitivity reaches 100\% (Oved et al. 2015; Herberg et al. 2016; Mahajan et al. 2016). These investigations are preliminary and have limitations. More recently, in a double-blind international multi-center study, 577 children between the ages of 2-60 months were subjected to a host protein-based assay that measured CRP, tumor necrosis factor apoptosis-inducing ligand (TRAIL), and interferon $\gamma$ induced protein 10 (IT-10) that reached a sensitivity of $86.7 \%$ with a good NPV of 97.8\% for bacterial infections (van Houten et al. 2017).

\section{Summary and outlook}

In the not too distant future, parents may be able test their feverish child at home using a POCT that reliably predicts both the pathogen and the danger of a severe complicated infection within minutes (Bauchner 2016). Until then, we must contend with the conventional single laboratory inflammatory marker that measures a non-specific immune response to an inflammatory stimulus; whether it be infection, trauma, tumor, or otherwise. Its current sensitivity or NPV is insufficient, resulting in either over treatment or insufficient detection of children at risk. The common view among practicing physicians that markedly raised 
Table 4: Statements regarding inflammation biomarkers.

\begin{tabular}{|c|c|}
\hline No evidence (non-sense) & Evidence (sense) \\
\hline $\begin{array}{l}\text { An elevation of inflammatory biomarkers is equivalent to an } \\
\text { infection }\end{array}$ & - \\
\hline $\begin{array}{l}\text { Markedly elevated classical laboratory biomarkers for } \\
\text { inflammation (e.g., CRP above } 50 \mathrm{mg} / \mathrm{L} \text {; PCT above } \\
0.5 \mathrm{ng} / \mathrm{mL} \text { ) in a child are evidence for a severe bacterial } \\
\text { infection }\end{array}$ & $\begin{array}{l}\text { Statistically, values for classical laboratory biomarkers (CRP, } \\
\text { PCT) are significantly higher in bacterial as compared to viral } \\
\text { infections, however, in the individual case very high values } \\
\text { are not uncommon in viral infections }\end{array}$ \\
\hline $\begin{array}{l}\text { Biomarkers are superior to standardized clinical judgement in } \\
\text { regard to prediction of an severe bacterial infection SBI }\end{array}$ & $\begin{array}{l}\text { Analysis of biomarkers should only be initiated if there are } \\
\text { clinical biomarkers indicating a severe bacterial infection } \\
\text { (e.g. in neonates premature rupture of membranes, maternal } \\
\text { fever) }\end{array}$ \\
\hline $\begin{array}{l}\text { Screening of all newborns, toddlers, school-children and } \\
\text { adolescents in emergency care for biomarkers like CRP } \\
\text { leads to a higher detection rate of severe bacterial infection } \\
\text { SBI and reduces antibiotics consumption }\end{array}$ & $\begin{array}{l}\text { The use of clinical biometric biomarkers (e.g., history and } \\
\text { physical examination) and laboratory biomarkers is the most } \\
\text { successful approach to the early detection of severe } \\
\text { bacterial infections SBI }\end{array}$ \\
\hline $\begin{array}{l}\text { In children with oncologic diseases and aplasia the use of } \\
\text { laboratory biomarkers e.g., CRP for the detection of SBI and } \\
\text { monitoring of therapy is evidence-based and irreplaceable }\end{array}$ & $\begin{array}{l}\text { Strong data are missing that show the successful use of } \\
\text { laboratory biomarkers for diagnosis, monitoring and therapy } \\
\text { of children in aplasia who present with the suspicion of an } \\
\text { infection }\end{array}$ \\
\hline $\begin{array}{l}\text { Monitoring of infections and their therapy by laboratory } \\
\text { biomarkers shows a strong evidence base any age and } \\
\text { leads to a better outcome than clinical judgement alone }\end{array}$ & $\begin{array}{l}\text { The use of laboratory biomarkers with a short half-life (IL-6, } \\
\text { IL-8) in newborns is suitable for the detection of SBI in } \\
\text { newborns. CRP can be used for the monitoring of therapy in } \\
\text { newborns with SBI }\end{array}$ \\
\hline
\end{tabular}

Note: The table is adapted from Niehues 2017.

inflammatory markers are equal to bacterial infection needs to be challenged (Table 4). At present, for SBI detection, there is no clear evidence that CRP or other laboratory inflammatory markers are in any way superior to clinical assessment by experienced nurses and physicians. Thus, these values should only supplement clinical judgement. Damage resulting from incorrect interpretation of laboratory results includes venipuncture and more invasive interventions such as lumbar puncture, unnecessarily long antibiotic therapy, or hospital stay. The use of inflammatory markers in dayto-day clinical practice results in over diagnosis as described by Anne van den Bruel in her publication "The triumph of medicine. How over diagnosis is turning healthy people into patients" (Van den Bruel 2015). Until sufficiently sensitive and specific technologies take over, the use of experienced clinical judgement in conjunction with cytokines, classical and hematological markers will be key to the early diagnosis of SBI.

\section{List of abbreviations}
$A P P \quad$ Acute-Phase-Protein
$A P R \quad$ Acute-Phase-Reaction
ESR Erythrocyte sedimentation rate
$C D$ Cluster of differentiation
CRP C-reactive Protein

CSF Cerebrospinal fluid

CXCL8 CXC-Motive-Chemokine Ligand 8 (Interleukin-8)

D/PAMP Damage/pathogen-associated molecular pattern

$F c R \gamma \quad$ Fc-Receptor- $\gamma$

GBS Group-B-Streptococci

G-CSF Granulocyte-colony stimulating factor

GM-CSF Granulocyte-monocyte- colony stimulating factor

IBI Invasive Bacterial Infection (Bacteremia, Sepsis, Meningitis)

IFN Interferon

IL Interleukin

IP-10 Interferon-gamma induced protein 10"

LPS Lipopolysaccharide

$N P V$ Negative predictive value

$P C$ Phosphocholine

pCAP Pediatric community-acquired pneumonia

$P C T$ Procalcitonin

$P P V$ Positive predictive value

$P R R$ Pattern recognition receptor

$R S V \quad$ Respiratory Syncytial Virus

SBI Severe bacterial infection (Sepsis, Meningitis, Appendicitis, Pneumonia, Osteomyelitis, Cellulitis, Bacterial Gastroenteritis, Complicated Urinary Tract Infection) 
TNF- $\alpha$ Tumor-Necrosis-Factor- $\alpha$

TRAIL Tumor necrosis factor apoptosis inducing ligand

WBC White blood cells

\section{Conflicts of interests}

Tim Niehues receives honoraria as an author/ reviewer from up2date.com

\section{Acknowledgements}

Without the careful and skilled help of Andrea Groth the preparation of this manuscript would not have been possible. I thank Marion Riffelmann, Peter Heister and Gregor Dückers (all at Helios Klinikum Krefeld, Germany) for helpful discussions.

\section{REFERENCES}

Appenzeller, C., Ammann, R.A., Duppenthaler, A., Gorgievski-Hrisoho, M., and Aebi, C. 2002. Serum C-reactive protein in children with adenovirus infection. Swiss Med. Wkly. 132:345-350. PMID: 12422291.

Bauchner, H. 2016. Genetics and the evaluation of the febrile child. JAMA. 316:824-825. PMID: 27552615. doi: 10.1001/jama.2016.11137.

Biomarkers Definitions Working Group. 2001. Biomarkers and surrogate endpoints: Preferred definitions and conceptual framework. Clin. Pharmacol. Ther. 69:89-95. doi: 10.1067/mcp.2001.113989.

Bomela, H.N., Ballot, D.E., Cory, B.J., and Cooper, P.A. 2000. Use of C-reactive protein to guide duration of empiric antibiotic therapy in suspected early neonatal sepsis. Pediatr. Infect. Dis. J. 19:531-535. PMID: 10877168. doi: 10.1097/00006454-200006000-00008.

Bradley, J.S., Byington, C.L., Shah, S.S., Alverson, B., Carter, E.R., Harrison, C., Kaplan, S.L., Mace, S.E., Mccracken, G.H., Jr., Moore, M.R., St Peter, S.D., Stockwell, J.A., Swanson, J.T., and Pediatric Infectious Diseases Society and the Infectious Diseases Society of America. 2011. The management of community-acquired pneumonia in infants and children older than 3 months of age: Clinical practice guidelines by the Pediatric Infectious Diseases Society and the Infectious Diseases Society of America. Clin. Infect. Dis. 53:e25-e76. PMID: 21880587. doi: $10.1093 /$ cid/cir531.
Chiesa, C., Osborn, J.F., Pacifico, L., Natale, F., and de Curtis, M. 2011. Gestational- and age-specific CRP reference intervals in the newborn. Clin. Chim. Acta. 412:1889-1890. PMID: 21723856. doi: 10.1016/j.cca.2011.06.022.

Dagan, R., Powell, K.R., Hall, C.B., and Menegus, M.A. 1985. Identification of infants unlikely to have serious bacterial infection although hospitalized for suspected sepsis. J. Pediatr. 107:855-860.

du Clos, T.W. 2013. Pentraxins: Structure, function, and role in inflammation. ISRN Inflamm. 2013:379040.

Dupuy, A.M., Philippart, F., Pean, Y., Lasocki, S., Charles, P.E., Chalumeau, M., Claessens, Y.E., Quenot, J.P., Guen, C.G., Ruiz, S., Luyt, C.E., Roche, N., Stahl, J.P., Bedos, J.P., Pugin, J., Gauzit, R., Misset, B., Brun-Buisson, C., and Maurice Rapin Institute Biomarkers Group. 2013. Role of biomarkers in the management of antibiotic therapy: an expert panel review: I-currently available biomarkers for clinical use in acute infections. Ann. Intensive Care. 3:22. PMID: 23837559. doi: 10.1186/2110-5820-3-22.

Ehl, S., Gering, B., Bartmann, P., Hogel, J., and Pohlandt, F. 1997. C-reactive protein is a useful marker for guiding duration of antibiotic therapy in suspected neonatal bacterial infection. Pediatrics, 99:216-221. PMID: 9024449. doi: 10.1542/peds. 99.2.216.

Friedman, J.N., Rieder, M.J., Walton, J.M., and Canadian Paediatric Society, Acute Care Committee, Drug Therapy and Hazardous Substances Committee. 2014. Bronchiolitis: Recommendations for diagnosis, monitoring and management of children one to 24 months of age. Paediatr. Child Health. 19:485-491. PMID: 25414585. doi: 10.1093/pch/19.9.485.

Haeusler, G.M., Mechinaud, F., Daley, A.J., Starr, M., Shann, F., Connell, T.G., Bryant, P.A., Donath, S., and Curtis, N. 2013. Antibiotic-resistant Gramnegative bacteremia in pediatric oncology patientsrisk factors and outcomes. Pediatr. Infect. Dis. J. 32:723-726. PMID: 23838774. doi: 10.1097/INF. 0b013e31828aebc8.

Hedegaard, S.S., Wisborg, K., and Hvas, A.M. 2015. Diagnostic utility of biomarkers for neonatal sepsis - a systematic review. Infect. Dis. (Lond). 47: 117-124. doi: 10.3109/00365548.2014.971053.

Herberg, J.A., Kaforou, M., Wright, V.J., Shailes, H., Eleftherohorinou, H., Hoggart, C.J., Cebey-Lopez, M., Carter, M.J., Janes, V.A., Gormley, S., Shimizu, C., Tremoulet, A.H., Barendregt, A.M., Salas, A., Kanegaye, J., Pollard, A.J., Faust, S.N., Patel, S., Kuijpers, T., Martinon-Torres, F., Burns, J.C., 
Coin, L.J., Levin, M., and Consortium, I. 2016. Diagnostic test accuracy of a 2 -transcript Host RNA signature for discriminating bacterial vs viral infection in febrile children. JAMA. 316:835-845. PMID: 27552617. doi: 10.1001/jama.2016.11236.

Hornik, C.P., Benjamin, D.K., Becker, K.C., Benjamin, D.K., Jr., Li, J., Clark, R.H., Cohen-Wolkowiez, M., and Smith, P.B. 2012. Use of the complete blood cell count in late-onset neonatal sepsis. Pediatr. Infect. Dis. J. 31:803-807. PMID: 22531232. doi: 10.1097/ INF.0b013e31825691e4.

Jaskiewicz, J.A., Mccarthy, C.A., Richardson, A.C., White, K.C., Fisher, D.J., Dagan, R., and Powell, K.R. 1994. Febrile infants at low risk for serious bacterial infection-an appraisal of the Rochester criteria and implications for management. Febrile Infant Collaborative Study Group. Pediatrics. 94:390-396. PMID: 8065869.

Jin, M., and Khan, A.I. 2010. Procalcitonin: Uses in the clinical laboratory for the diagnosis of sepsis. Labmedicine. 41:173-177.

Kapasi, A.J., Dittrich, S., Gonzalez, I.J., and Rodwell, T.C. 2016. Host biomarkers for distinguishing bacterial from non-bacterial causes of acute febrile illness: A comprehensive review. PLoS ONE, 11:e0160278. PMID: 27486746. doi: 10.1371/journal.pone.0160278.

Karakurt, D.G., Demirsoy, U., Corapcioglu, F., Oncel, S., Karadogan, M., and Arisoy, E.S. 2014. Do proinflammatory cytokine levels predict serious complication risk of infection in pediatric cancer patients? Pediatr. Hematol. Oncol. 31:415-424. PMID: 24499434. doi: 10.3109/08880018.2013.848387.

Kruger, S., Ewig, S., Papassotiriou, J., Kunde, J., Marre, R., von Baum, H., Suttor, N., Welte, T., and Group, C.S. 2009. Inflammatory parameters predict etiologic patterns but do not allow for individual prediction of etiology in patients with CAP: Results from the German competence network CAPNETZ. Respir. Res. 10:65. PMID: 19594893. doi: 10.1186/1465-9921-10-65.

Kushner, I. 2015. Acute phase reactants. UpToDate. Wolters Kluwer.

Lehmann, C., Berner, R., Bogner, J.R., Cornely, O.A., de With, K., Herold, S., Kern, W.V., Lemmen, S., Pletz, M.W., Ruf, B., Salzberger, B., Stellbrink, H.J., Suttorp, N., Ullmann, A.J., Fatkenheuer, G., and Jung, N. 2017. The "Choosing Wisely" initiative in infectious diseases. Infection. 45:263-268. PMID: 28290130. doi: 10.1007/s15010-017-0997-0.

Lin, S.G., Hou, T.Y., Huang, D.H., He, S.Y., Lin, Y.D., Zhang, L.Y., and Hsieh, P.S. 2012. Role of procalcitonin in the diagnosis of severe infection in pediatric patients with fever and Neutropenia-a systemic review and meta-analysis. Pediatr. Infect. Dis. J. 31: e182-e188. PMID: 22592515.

Linscheid, P., Seboek, D., Nylen, E.S., Langer, I., Schlatter, M., Becker, K.L., Keller, U., and Muller, B. 2003. In vitro and in vivo calcitonin I gene expression in parenchymal cells: a novel product of human adipose tissue. Endocrinology. 144:5578-5584. PMID: 12960010. doi: 10.1210/en.2003-0854.

Liu, R.S., Aiello, A.E., Mensah, F.K., Gasser, C.E., Rueb, K., Cordell, B., Juonala, M., Wake, M., and Burgner, D.P. 2017. Socioeconomic status in childhood and $\mathrm{C}$ reactive protein in adulthood: A systematic review and meta-analysis. J. Epidemiol. Community Health. 71:817-826. PMID: 28490476. doi: 10.1136/jech2016-208646.

Machado, J.R., Soave, D.F., da Silva, M.V., de Menezes, L.B., Etchebehere, R.M., Monteiro, M.L., Dos Reis, M.A., Correa, R.R., and Celes, M.R. 2014. Neonatal sepsis and inflammatory mediators. Mediators Inflamm. 2014:269681.

Mahajan, P., Kuppermann, N., Mejias, A., Suarez, N., Chaussabel, D., Casper, T.C., Smith, B., Alpern, E.R., Anders, J., Atabaki, S.M., Bennett, J.E., Blumberg, S., Bonsu, B., Borgialli, D., Brayer, A., Browne, L., Cohen, D.M., Crain, E.F., Cruz, A.T., Dayan, P.S., Gattu, R., Greenberg, R., Hoyle, J.D., Jr., Jaffe, D.M., Levine, D.A., Lillis, K., Linakis, J.G., Muenzer, J., Nigrovic, L.E., Powell, E.C., Rogers, A.J., Roosevelt, G., Ruddy, R.M., Saunders, M., Tunik, M.G., Tzimenatos, L., Vitale, M., Dean, J.M., Ramilo, O., and for the Pediatric Emergency Care Applied Research Network (PECARN). 2016. Association of RNA biosignatures with bacterial infections in febrile infants aged 60 days or younger. JAMA, 316:846-857. PMID: 27552618. doi: 10.1001/jama.2016.9207.

Milcent, K., Faesch, S., Gras-le Guen, C., Dubos, F., Poulalhon, C., Badier, I., Marc, E., Laguille, C., de Pontual, L., Mosca, A., Nissack, G., Biscardi, S., le Hors, H., Louillet, F., Dumitrescu, A.M., Babe, P., Vauloup-Fellous, C., Bouyer, J., and Gajdos, V. 2016. Use of procalcitonin assays to predict serious bacterial infection in young febrile infants. JAMA Pediatr, 170:62-69. PMID: 26595253. doi: 10.1001/ jamapediatrics.2015.3210.

Niehues, T. 2013. The febrile child: diagnosis and treatment. Dtsch. Arztebl. Int. 110, 764-773; quiz 774. PMID: 24290365. doi: 10.3238/arztebl.2013.0764.

Niehues, T. 2017. C-reaktives Protein und andere immunologische Biomarker. Monatsschrift Kinderheilkunde, 165:560-571. 
Nuriel-Ohayon, M., Neuman, H., and Koren, O. 2016. Microbial changes during pregnancy, birth, and infancy. Front Microbiol. 7:1031. PMID: 27471494. doi: $10.3389 /$ fmicb.2016.01031.

Oved, K., Cohen, A., Boico, O., Navon, R., Friedman, T., Etshtein, L., Kriger, O., Bamberger, E., Fonar, Y., Yacobov, R., Wolchinsky, R., Denkberg, G., Dotan, Y., Hochberg, A., Reiter, Y., Grupper, M., Srugo, I., Feigin, P., Gorfine, M., Chistyakov, I., Dagan, R., Klein, A., Potasman, I., and Eden, E. 2015. A novel host-proteome signature for distinguishing between acute bacterial and viral infections. PLoS ONE, 10:e0120012. PMID: 25785720. doi: 10.1371/journal. pone.0120012.

Phillips, R.S., Wade, R., Lehrnbecher, T., Stewart, L.A., and Sutton, A.J. 2012. Systematic review and metaanalysis of the value of initial biomarkers in predicting adverse outcome in febrile neutropenic episodes in children and young people with cancer. BMC Med. 10:6. PMID: 22257704. doi: 10.1186/17417015-10-6.

Simons, J.P., Loeffler, J.M., Al-Shawi, R., Ellmerich, S., Hutchinson, W.L., Tennent, G.A., Petrie, A., Raynes, J.G., de Souza, J.B., Lawrence, R.A., Read, K.D., and Pepys, M.B. 2014. C-reactive protein is essential for innate resistance to pneumococcal infection. Immunology. 142:414-420. PMID: 24673624. doi: $10.1111 / \mathrm{imm} .12266$.

Slaats, J., Ten Oever, J., van de Veerdonk, F.L., and Netea, M.G. 2016. IL-1beta/IL-6/CRP and IL-18/ferritin: Distinct inflammatory programs in infections. PLoS Pathog. 12:e1005973. PMID: 27977798. doi: 10.1371/ journal.ppat.1005973.

Strimbu, K., and Tavel, J.A. 2010. What are biomarkers? Curr. Opin. HIV AIDS. 5:463-466. PMID: 20978388. doi: 10.1097/COH.0b013e32833ed177.

Toikka, P., Irjala, K., Juven, T., Virkki, R., Mertsola, J., Leinonen, M., and Ruuskanen, O. 2000. Serum procalcitonin, C-reactive protein and interleukin-6 for distinguishing bacterial and viral pneumonia in children. Pediatr. Infect. Dis. J. 19:598-602. PMID: 10917215. doi: 10.1097/00006454-20000700000003.

Thompson, M., van den Bruel, A., Verbakel, J., Lakhanpaul, M., Haj-Hassan, T., Stevens, R., Moll, H., Buntinx, F., Berger, M., Aertgeerts, B., Oostenbinrk, R., and Mant, D. 2012. Systematic review and validation of prediction rules for identifying children with serious infections in emergency departments and urgent-access primary care. Health Technol Assess, 16, 1-100.

van den Bruel, A. 2015. The triumph of medicine: How overdiagnosis is turning healthy people into patients. Fam. Pract. 32:127-128. PMID: 25805809. doi: 10.1093/fampra/cmv008.

van den Bruel, A., Haj-Hassan, T., Thompson, M., Buntinx, F., Mant, D., and European Research Network on Recognising Serious Infection Investigators. 2010. Diagnostic value of clinical features at presentation to identify serious infection in children in developed countries: A systematic review. Lancet. 375:834-845. PMID: 20132979. doi: 10.1016/ S0140-6736(09)62000-6.

van den Bruel, A., Thompson, M. J., Haj-Hassan, T., Stevens, R., Moll, H., Lakhanpaul, M., and Mant, D. 2011. Diagnostic value of laboratory tests in identifying serious infections in febrile children: systematic review. BMJ, 342, d3082.

van den Bruel, A., Thompson, M., Buntinx, F., and Mant, D. 2012. Clinicians' gut feeling about serious infections in children: Observational study. BMJ. 345:e6144. PMID: 23015034. doi: 10.1136/bmj.e6144. van den Bruel, A., Jones, C., Thompson, M., and Mant, D. 2016. C-reactive protein point-of-care testing in acutely ill children: A mixed methods study in primary care. Arch. Dis. Child. 101:382-386. PMID: 26757989. doi: 10.1136/archdischild-2015309228.

van Houten, C.B., de Groot, J.A.H., Klein, A., Srugo, I., Chistyakov, I., de Waal, W., Meijssen, C. B., Avis, W., Wolfs, T.F.W., Shachor-Meyouhas, Y., Stein, M., Sanders, E.A.M., and Bont, L.J. 2017. A host-protein based assay to differentiate between bacterial and viral infections in preschool children (OPPORTUNITY): A double-blind, multicentre, validation study. Lancet Infect. Dis. 17:431-440. PMID: 28012942. doi: 10.1016/S1473-3099(16) 30519-9.

Verbakel, J.Y., Lemiengre, M.B., de Burghgraeve, T., de Sutter, A., Aertgeerts, B., Shinkins, B., Perera, R., Mant, D., van den Bruel, A., and Buntinx, F. 2016. Should all acutely ill children in primary care be tested with point-of-care CRP: A cluster randomised trial. BMC Med. 14:131. PMID: 27716201. doi: 10.1186/s12916-016-0679-2.

Waage, A., Brandtzaeg, P., Halstensen, A., Kierulf, P., and Espevik, T. 1989. The complex pattern of cytokines in serum from patients with meningococcal 
septic shock. Association between interleukin 6, interleukin 1, and fatal outcome. J. Exp. Med. 169:333-338. PMID: 2783334. doi: 10.1084/jem. 169.1.333.

Yo, C.H., Hsieh, P.S., Lee, S.H., Wu, J.Y., Chang, S.S., Tasi, K.C., and Lee, C.C. 2012. Comparison of the test characteristics of procalcitonin to C-reactive protein and leukocytosis for the detection of serious bacterial infections in children presenting with fever without source: A systematic review and meta-analysis. Ann. Emerg. Med. 60:591-600. PMID: 22921165. doi: 10.1016/j.annemergmed.2012.05.027.
Zhang, H., Morrison, S., and Tang, Y. 2015. Multiplex PCR tests for detection of pathogens associated with gastroenteritis. Clin. Lab. Med. 35:461-486. PMID: 26004652. doi: 10.1016/j.cll.2015. 02.006 .

Ziegler, I., Fagerstrom, A., Stralin, K., and Molling, P. 2016. Evaluation of a commercial multiplex PCR assay for detection of pathogen DNA in blood from patients with suspected sepsis. PLoS ONE. 11: e0167883. PMID: 27997618. doi: 10.1371/journal. pone. 0167883 . 